\title{
IT Infrastructures Maintenance and Evolution in Public Sector Organizations: Main Challenges
}

\author{
Simon Bourdeau \\ UQAM \\ bourdeau.s@uqam.ca
}

\author{
Dragos Vieru \\ TÉLUQ University \\ dragos.vieru@teluq.ca
}

\author{
Thibaut Coulon \\ HEC Montréal \\ thibaut.coulon@hec.ca
}

\author{
Élodie Boissières \\ TÉLUQ University \\ elodie.boissieres@teluq.ca
}

\begin{abstract}
In the face of rapid and constant technological evolution, the management of IT infrastructures in an effective and sustainable manner represents a major challenge for any organization and even more for public sector organizations (PSOs) who often lack IT resources and expertise. PSOs are social and economic actors who must spend taxpayers' money in a responsible and efficient manner. Despite the importance of these challenges for practitioners and academics alike, there is a limited number of studies in this field. The present study seeks to fill this gap through a systematic review of the literature followed by a Delphi study. Outcomes of this literature review are presented along with preliminary results of a Delphi study realized with 40 IT infrastructure experts.
\end{abstract}

\section{Introduction}

For several years, public sector organizations (PSOs) have undergone many changes, not only in their governance structures and managerial approaches, but also in the management of their information technologies (IT) infrastructures. According to Rosacker and Rosacker [1], IT infrastructures represents one of the biggest concern in PSOs as indicated by the growing financial resources invested in IT projects each year. However, compared to private organizations, PSOs face several other challenges such as the transparency and efficiency required in their IT-related expenditures and the lack of expertise in IT. For example, when procuring products or services, PSOs are governed by principles of transparency and non-discriminatory competition, by regulations to prevent corruption, or by the fact that they must trade on public markets $[2,3]$.

Nowadays, to overcome these challenges, more and more PSOs are turning to external suppliers to develop, acquire, maintain and upgrade their IT infrastructures, both the hardware and the software dimensions $[4,5]$. The development, acquisition, maintenance and evolution of IT infrastructures, through IT public procurement, represent several challenges for PSOs [6-8]. In fact, since IT infrastructures are continually evolving, increasingly complex, and must respond to the needs of various PSO's stakeholders, the provision and management of these infrastructures are often a headache for the managers responsible for them. According to Tizard [9] PSOs face severe financial pressures and cuts, higher and higher public and user expectations, and an acute lack of qualified people.

Despite their importance, the activities and practices related to the supply and management of IT infrastructures in PSOs have been scarcely studied and documented in both academic and professional literatures [3]. It appears to be a significant lack of knowledge on the challenges faced by PSOs regarding the maintenance and evolution of their IT infrastructures as well as how PSOs should effectively and sustainably manage their IT infrastructures.

The literature suggests that PSOs need to adapt to a constant technological evolution driven by performance / capacity enhancements, functionalities additions, and frequent updates of new releases [10]. Therefore, the present study tries to fill this gap through both a systematic review of the literature and a Delphi study, to answer the main research question:

What are the main challenges associated with the evolution and maintenance of IT infrastructures in the public sector context?

Our study seeks to shed light on the specific challenges that PSOs need to address to meet the increasing expectations of performance and quality of the IT infrastructures by differentiate them from the challenges encountered by private sector firms.

The next section presents the literature review and the outcomes of this exercise followed by the presentation of the preliminary results of the Delphi study $[11,12]$. 


\section{Literature Review: IT Infrastructures Management Challenges Faced by PSO}

To carry out the literature review, Paré et al.'s [13] recommendations were followed. As a first step, keywords relevant to the domain of interest and to the research question were identified. Because the first results were too broad since they included studies realized in private sector organizations, we decided to focus only on those realized in PSOs by adding the keyword "public sector". The exhaustive list of keywords used contained the terms: IT, information systems management, smart government, egovernment, procurement, e-procurement, IT management, IT outsourcing, big data management and IT infrastructure. Several databases were consulted: JSTOR, ACM Digital Library, ProQuest and Google Scholar aggregator. We focused on academic and empirical articles. Peer-reviewed articles published in journals or conferences have also been selected, as well as book chapters.

Our research also consisted of using the cross references mentioned in the articles and book chapters. Among the 55 articles identified after the first round, 20 articles that dealt more specifically with the role of IT managers in PSO were excluded as well as 15 other that focused on IT project techniques. Also, 8 other articles that focused on the IT identity crisis in the public sector were excluded. Finally, 11 articles analyzing the management of IT infrastructures in PSOs were kept and grouped into four categories: 1) Governance issues [14, 15]; 2) Procurement issues [5, 10,16]; 3) Outsourcing issues [17-19]; and 4) Big data and its implementation issues [20-22].

\subsection{IT Governance in the Public Sector}

According to Campbell et al. [14], IT governance represents a collection of relationships, processes, and mechanisms used for the development, control, conduct of an IT strategy. Conversely, IT management focuses more on the internal operations and the administration of existing IT infrastructures. IT management tasks are more locally focused and applied to a lower level, e.g. operations, while IT governance is located at a higher organizational level with an extended overview [23]. The literature suggests that PSOs, like any organization from the private sector, have difficulties adopting IT infrastructure governance policies.

However, unlike the fimrs in the private sector, PSOs: 1) face multiple contradictory objectives; 2) have to respond to many stakeholders who often have competing interests; and 3) have to deal with several specific risks such as, lack of support/consensus from stakeholders, lack of technical expertise, and difficulties to respect governing principles and regulations [24].

In their empirical study, Campbell et al. [14] identify two types of challenges faced by PSOs regarding IT governance: 1) infrastructure-related and 2) process-related. From an infrastructure perspective, PSOs usually have short-term budgets, i.e. annual budget, but must consider the needs, the uncertainty and the availability of future resources which could span over several years. They also have limited technical expertise [24].

From a process point of view, PSOs have to deal with numerous and competitive stakeholders who have different objectives and needs. However, PSOs' managers decisions are constrained by the compliance to government rules and laws as well as by very strict procurement policies [14]. Furthermore, according to Cordella and Iannacci [25], these rules, laws, and policies influence how IT infrastructures are managed and it seems, not always in the best interests of the PSOs or the citizens. In an attempt to respond to these challenges, Dawes et al. [24] conceptualize IT initiatives in the public sector as a complex set of intricate and interrelated layers that significantly delineate IT development projects: 1) Programs, policies and political context should dictate $\rightarrow 2$ ) the organizational settings that should determine $\rightarrow 3$ ) the business processes that ultimately should guide $\rightarrow 4$ ) the decisions related to IT infrastructures.

Another challenge faced by PSOs is the emergence of "smart-governments" portrayed as governments that use consolidated information systems and communication networks to address financial, environmental, and service challenges [26]. According to Gil-Garcia et al. [15], the emergence of smart governments, have led to changes in PSOs' IT infrastructures. Usually smart governments need to use new technologies and new innovation strategies to better understand their communities and constituents. Therefore, PSOs must to implement new and upgraded applicative infrastructures to meet new information needs [27]. The effects of these challenges can be mitigated by implementing proper IT governance in PSO.

Juiz et al. [28] propose a governance model for PSOs. They argue that, by establishing good IT governance structures, PSOs should increase the value creation and the transparency of their IT investments. The authors also propose a standard that establishes six governance principles to guide IT infrastructure decision-making: accountability, strategy, acquisition, performance, compliance, and human behavior. Similarly, Dawson et al. [29], suggest that the 
establishment of a legislative oversight committee will increase the performance of the PSOs' IT departments.

\subsection{IT Procurement in the Public Sector}

The emergence of smart governments triggers the need for new IT infrastructure requirements related to IT procurement challenges [15]. Moe and Päivärinta [10] identify several issues regarding IT procurement in PSOs, such as contradictory and conflicting demands from multiple stakeholders, lack of clarity between objectives and ambiguity of some objectives, need for transparency in sourcing contracts, analyzing and writing IT requirements, financial management of contracts, organizational processes changes, IT benefits identification and materialization, and technological compatibility and integration. However, one would wonder, how can PSOs supply the best IT solutions possible while simultaneously following the strict rules imposed governmental laws and policies? [5]

Trying to answer this question, Moe et al. [5] propose four strategies: 1) open tendering, i.e. requirements and needs are expressed in the call for tenders, everyone can respond to the bid); 2) restricted tendering, i.e. a number of pre-qualified vendors are identified; 3) tendering with negotiations, i.e. after the submission, the pre-qualified vendors enter into negotiations with PSOs on all aspects of the submission; and 4) competitive dialogue, i.e. PSOs can start the dialogue with pre-qualified organizations before establishing selection criteria and presenting sellers' offers.

However, these strategies partially address the problem since PSOs have constraints that private organizations do not necessarily have. For instance, whereas private organizations view their IT as proprietary systems, public organizations provide "public goods" [30]. Following this line, the European Union Public Procurement Directive of 2016, requires that all its members must ensure that all purchasing procedures are based on IT bids that were made electronically [16].

Thus, IT procurement in the public sector is structured on two levels. At the global level, PSOs must follow the general rules, policies and laws whereas at local level, PSOs must optimize the management of their IT infrastructures where constraints and directives are too heavy. Furthermore, the resources allocations to the various PSOs units do not allow them to adequately identify their IT global needs and how to comply with larger IT requirements. In conclusion, the introduction of new procurement guidelines in the public sector would reinforce the need for IT governance in PSOs.

\subsection{IT Outsourcing in the Public Sector}

Another challenge faced by PSOs regarding the management of their IT infrastructure is related to outsourcing. In his study, de Looff [31] does not see IT outsourcing in the public sector as an advantage since this practice would result in the privatization of some of the information systems and thus lose control of them. Moreover, by outsourcing their IT infrastructures, the access, the security, and the management of information become more complicated and uncertain for PSOs. Despite these preoccupations, IT outsourcing in the public sector has increased because of the difficulties PSOs have in keeping pace with technological changes and with the growing complexity of the in-house support of the IT resources and capacities [32]. Duhamel et al. [19] propose to focus on institutional measures and organizational factors that can influence and limit IT outsourcing in PSOs. These authors identify three variables that need to be taken into consideration to foster dialogue between PSOs and the IT outsourcing service providers: 1) mutual trust; 2) knowledge sharing; and 3) a common organizational culture.

Nevertheless, IT outsourcing can also engender benefits for PSOs. For instance, IT outsourcing can relieve PSOs from the need to maintain their IT infrastructure as well as preserving significant technical expertise internally and thereby reducing their overhead costs while keeping a high level of flexibility [18]. Gantman [17] finds that IT outsourcing not only reduces costs, but it also represents a means to achieve strategic objectives and have access to valuable resources. Thus, to meet the needs of their various stakeholders, to respond to innovation demands and to reduce the vagaries of government directives and frequent political changes, IT outsourcing can be an alternative solution for POSs.

\subsection{Big Data Challenges in the Public Sector}

Based on their role and mission, PSOs need to collect enormous amounts of data. Big data represents a large volume of data that is routinely produced by organizations and is too complex for standard processing software [33]. According to Mullich [34], while private sector is moving ahead with the use of big data, public sector is lagging behind. According to Milakovich [35], this is very damaging since big data could added real value by enabling PSOs to improve their efficiency, effectiveness, and the transparency of their processes and practices. However, according to Margetts and Sutchliffe [36], the use of big data would represent new challenges for PSOs represented mainly by new information security threats. 
To respond to these new challenges, Klievink et al. [20] identify three components that could influence a PSO's readiness to use big data: 1) the organizational alignment, i.e. does the PSO know why and how to use big data? 2) the organizational maturity, i.e. what is the PSO's level of maturity in terms of e-government practices? and 3) the organizational capabilities, i.e. does the PSO have the IT infrastructure and resources to use big data to create value for the organization without causing negative consequences?

Research conducted by McKinsey Global Institute suggests that the deployment of big data technology in the European public sector would enable PSOs to reduce their operating costs by $20 \%$ and create $300 €$ billions in value added [37]. However, according to Malomo and Sena [38], in 2013 the public sector did not have the skills to cope with the major changes involved in storing and managing data from database platforms. In addition, several authors have also pointed out that public sector data cannot be considered as big data because of their size, diversity and variety $[39,40]$. According to Chambers et al. [41] and Thakuriah et al. [42] two reasons support these arguments: 1) public sector data tend to be generated from administrative records of users and therefore can be considered structured and static; and 2) it is generally assumed that public sector data are not granular enough for analysts to infer a specific phenomenon. Thus, Malomo and Sena [38] determine that the major obstacle in using big data in PSOs is related to the existence of data silos resulted from the fragmentation of activities within PSOs.

In addition, PSOs are facing several other obstacles regarding the use of big data, such as: 1) the issue of information accessibility, i.e. allowing information sharing by several actors of PSOs and creating a collaborative network; 2) ethical issues i.e. dilemma between extraction and manipulation and crossreferencing of personal information within different services; 3) organizational changes, i.e. data technologies can be used as levers for introducing future changes; and 4) disparate IT investments, i.e. budget irregularities and lack of investment in internal skills related to the development of big data technologies [38, 43]. In this vein, developing successful IT infrastructures for big data in PSOs would require: 1) general legal models that facilitate information sharing between different PSO's sectors; 2) update IT infrastructures in all sectors and implement a plan to improve the skills of the existing workforce; and 3) get support from senior management especially when data silos exist between sectors [38].

\section{Delphi Study: IT Infrastructures Management Challenges Faced by PSOs}

Although the outcomes of our literature review show that PSOs face important challenges, the number of articles identified (11) is small, as well as the range of challenges identified regarding the management of IT infrastructure. Thus, in order to shed a better light on the challenges faced by IT infrastructure managers in public sector a Delphi study was conducted $[11,12]$. This method allows a panel of experts to communicate and exchange, in an interactive and structured way, to identify, select and classify different ideas such as problems, key success factors or good practices [11, $44,45]$. The Delphi method was chosen because it has been used successfully in complex areas requiring expert judgments [e.g. 44]. It has also been shown to be effective in identifying IT challenges, problems and solutions [12].

The Delphi method helps formalizing communications and information sharing between experts to extract the challenges they face when managing IT infrastructure. The method also provides objective information based on the experience and expertise of all experts. Thus, as the Delphi method serves as a tool to help identify issues and practices, it is well suited for the targeted research objective. Furthermore, Delphi's method main features, i.e. 1) anonymity, 2) multiple iterations, 3) controlled feedback and 4) statistical aggregation of group responses, will help reach this objective [11]. We followed the suggested steps to conducted a Delphi study [44, 45] as well as the recommendations formulated by experts [11] in the elaboration of the methodological design.

In the present study, out of the 62 IT infrastructure management experts that were contacted, 40 accepted to participate in the study. Since the managers managing IT infrastructures in the public sector and the ones managing IT in the private sector probably face similar challenges, we extended the Delphi study to the private sector. In addition, to have a complementary perspective, as well as to be able to make comparisons between sectors, IT infrastructure experts from the academia were invited to participate in the study. The selection of these three groups of experts was based on each experts' varied experiences and expertise and the potential that each of them will provide diverging but complementary information, views and opinions. The authors' personal contacts in LinkedIn were used as the main source to identify the participants. To participate in the study, the experts had to have: 1) expertise in managing IT infrastructures and/or scientific research in the field; and 2) a minimum of 7-10 years of IT experience as 
practitioner or in research. Thus, the Delphi's participants were categorized as follows: public sector $(n=14)$, private sector $(n=15)$ and academic research sector $(n=11)$. On average, the participants were 47,1 years old, had 23,1 years of work experience and had 17,5 years of IT experience. Thirty-eight (38) participants were males and two (2) were females.

During the Delphi study, experts had to identify and classify issues related to the management of IT infrastructures. To do so, data collection process followed the three main phases underlying the Delphi method: 1) brainstorming; 2) narrowing; and 3) ranking $[11,12,46]$.

\subsection{Delphi Study: Preliminary Results}

Brainstorming phase. The Delphi study was launched in May 2018. In this first phase, the experts were asked to answer the following question: "What are the main challenges faced by organizations regarding the evolution and the maintenance of its IT infrastructure?". Each expert had to identify, if possible, 6 challenges. For each challenge, the experts were asked to name the challenge by providing a label as well as an explanation in order to avoid misunderstanding and misinterpretation.

In total, 217 different labels and explanations were received. As recommended by Delphi experts $[11,12$, 46], the list of challenges was consolidated since several challenge labels and explanations were very similar and/or overlapping. To conduct this consolidation, two of the authors performed a first individual round of consolidation grouping similar labels and explanations followed by a comparison of the two resulted lists. Around $85 \%$ of the elements were similarly consolidated on both lists. For the other $15 \%$, the two authors came to an agreement. The final consolidated list was then validated by the third author for conformity and clarity.

The consolidated list of labels and explanations was returned to each of the experts for validation. Thus, if some labels and/or explanations were unclear or did not reflect the initial experts' intent, each expert was asked to comment and/or provide elements and/or suggestions for changes or adjustments. Also, for each expert, the original labels and explanations that he or she provided were positioned next to the consolidated list of labels and explanations. Thus, each expert had the opportunity to validate that his or her labels and explanations were associated with the proper label and explanation. The objective of this validation was to make sure that the we correctly interpreted the experts' statements.

The complete list of challenges gathered in the brainstorming phase is presented in Appendix 1. In total, 38 different challenges were identified and grouped into six main categories (not classified in a particular order):

1) Strategic challenges, i.e., balancing the IT portfolio, flexibility of the IT infrastructure, compliance with laws, standards and regulations, structure and governance of the IT department, manage upper management's expectations and clarify the importance of infrastructure management;

2) Technological challenges, i.e., coherent infrastructure, understanding and documenting current infrastructure and architecture, complex integration of infrastructure, systems' interoperability;

3) Security challenges, i.e., data management in public and hybrid clouds, piracy and data security;

4) Human resources challenges, i.e., skill development, recruitment of employees, employee retention;

5) Financial resources and cost control challenges, i.e., limited resources for infrastructure management, license tracking; and

6) User related challenges, i.e., access to highperformance telecommunication infrastructures, users' needs.

Narrowing phase. In the second phase, the experts were asked to select, from the list with the 38 challenges, their top ten most important challenges, without classify them. Appendix 2 presents the aggregated results of the narrowing phase for each of the three groups of experts, i.e. from the private, public or academic sector. Based on these results, the main challenges faced by PSOs are relatively similar to those faced by private organizations as well as those identified by academics such as, skill development, flexibility of the IT infrastructure, and employee retention. The challenges specific to PSOs are: balancing the IT portfolio, rapid evolution of IT infrastructure components, and user needs.

Ranking phase. In the last phase the experts were asked to rank challenges identified by all the experts in the Narrowing phase by order of relative importance. Appendix 2 presents the aggregated preliminary results of the ranking phase. Based on a Kendall's W coefficient of 0.7 , the results presented here indicate a not very strong level of consensus [11, 45]. Thus, a necessary second round of Ranking is currently undergoing.

Based on these preliminary results, there seems to be some ranking convergence of the challenges between the three groups of experts. Indeed, the three 
groups of experts identified organizational transformation as their most important challenge. Structure and governance of IT department, employee retention, as well as knowledge management were also identified as key challenges by the three groups. Thus, with information gathered in the upcoming round, it will be possible to make a more accurate comparison between the three groups of experts in order to shed light on the challenges specific to public sector organizations (PSOs).

\section{Conclusion and Future Research}

With the rapid and constant technological evolution, PSOs face important challenges regarding the maintenance and evolution of their IT infrastructures as well as how to effectively and sustainably manage the IT infrastructures. Because the extant academic and practitioner literatures lack of pertinent studies on this important topic, this study is a first step to fill this gap by conducting a systematic review of the literature and a Delphi study.

Thus, in terms of challenges regarding the management of their IT infrastructure, PSOs are facing strategic, technological, security, human resources, financial and users related challenges.

The next step will be to identify practices/strategies used by public organizations to extend the durability of existing IT infrastructures and to anticipate and prepare for challenges related to the constant and rapid technological change.

\section{Acknowledgements}

This research project was funded by, and realized with the collaboration of the Center for Interuniversity Research and Analysis of Organizations - CIRANO (https://cirano.qc.ca/en).

\section{References}

[1] K. M. Rosacker and R. E. Rosacker, "Information technology project management within public sector organizations," Journal of Enterprise Information Management, vol. 23, no. 5, pp. 587-594, 2010.

[2] J. Edler and L. Georghiou, "Public procurement and innovation-Resurrecting the demand side," Research policy, vol. 36, no. 7, pp. 949-963, 2007.

[3] C. E. Moe, "Research on public procurement of information systems: the need for a process approach," Commun. Assoc. Inf. Syst, vol. 34, no. 1, p. 78, 2014.

[4] D. Edberg, P. Ivanova, and W. Kuechler, "Methodology mashups: An exploration of processes used to maintain software," Journal of Management Information Systems, vol. 28, no. 4, pp. 271-304, 2012.

[5] C. E. Moe, M. Newman, and M. K. Sein, "The public procurement of information systems: dialectics in requirements specification," European Journal of Information Systems, Vol.26, No.2, pp. 143-163, 2017.

[6] J. Edler and J. Yeow, "Connecting demand and supply: The role of intermediation in public procurement of innovation," Research Policy, vol. 45, no. 2, pp. 414426, 2016.

[7] C. Edquist and L. Hommen, "Public technology procurement and innovation theory," in Public technology procurement and innovation: Springer, 2000, pp. 5-70.

[8] W. Cats-Baril and R. Thompson, "Managing information technology projects in the public sector," Public Administration Review, pp. 559-566, 1995.

[9] J. Tizard, "The challenges and opportunities in contemporary public sector leadership," International Journal of Leadership in Public Services, vol. 8, no. 4, pp. 182-190, 2012.

[10] C. E. Moe and T. Päivärinta, "Challenges in information systems procurement in the public sector," Electronic journal of e-Government, vol. 11, no. 1, pp. 307-322, 2013.

[11] G. Paré, A.-F. Cameron, P. Poba-Nzaou, and M. Templier, "A systematic assessment of rigor in information systems ranking-type Delphi studies," (in English), Information \& Management, vol. 50, no. 5, pp. 207-217, 2013.

[12] C. Okoli and S. D. Pawlowski, "The Delphi method as a research tool: an example, design considerations and applications," Information \& Management, vol. 42, no. 1, pp. 15-29, 2004.

[13] G. Paré, M.-C. T. Trudel, M. Jaana, and S. Kitsiou, "Synthesizing information systems knowledge: A typology of literature reviews," Information \& Management, Vol.52, No.2, pp. 183-199, 2014.

[14] J. Campbell, C. McDonald, and T. Sethibe, "Public and private sector IT governance: Identifying contextual differences," Australasian Journal of Information Systems, vol. 16, no. 2, 2010.

[15] J. R. Gil-Garcia, N. Helbig, and A. Ojo, "Being smart: Emerging technologies and innovation in the public sector," Government Information Quarterly, vol. 31, pp. I1-I8, 2014.

[16] A. Bradić-Martinović, "E-procurement performance indicators: a step towards EU," Economic Analysis, pp. 38-61, 2016.

[17] S. Gantman, "IT outsourcing in the public sector: A literature analysis," Journal of Global Information Technology Management, vol. 14, no. 2, pp. 48-83, 2011.

[18] B. Burnes and A. Anastasiadis, "Outsourcing: a public-private sector comparison," Supply Chain Management: An International Journal, vol. 8, no. 4, pp. 355-366, 2003.

[19] F. Duhamel, I. Gutierrez-Martinez, S. Picazo-Vela, and L. Luna-Reyes, "IT outsourcing in the public sector: a conceptual model," Transforming Government: People, Process and Policy, vol. 8, no. 1, pp. 8-27, 2014.

[20] B. Klievink, B.-J. Romijn, S. Cunningham, and H. de Bruijn, "Big data in the public sector: Uncertainties 
and readiness," Information Systems Frontiers, vol. 19, no. 2, pp. 267-283, 2017.

[21] E. Kuiper, F. Van Dam, A. Reiter, and M. Janssen, "Factors influencing the adoption of and business case for Cloud computing in the public sector," in eChallenges e-2014, 2014 Conference, 2014, pp. 1-10: IEEE.

[22] G.-H. Kim, S. Trimi, and J.-H. Chung, "Big-data applications in the government sector," Communications of the ACM, vol. 57, no. 3, pp. 78-85, 2014.

[23] A. S. Sohal and P. Fitzpatrick, "IT governance and management in large Australian organisations," International Journal of Production Economics, vol. 75, no. 1-2, pp. 97-112, 2002.

[24] S. S. Dawes et al., Making smart IT choices: Understanding value and risk in government IT investments. The Center, 2004.

[25] A. Cordella and F. Iannacci, "Information systems in the public sector: The e-Government enactment framework," The Journal of Strategic Information Systems, vol. 19, no. 1, pp. 52-66, 2010.

[26] C. E. Jiménez, F. Falcone, A. Solanas, H. Puyosa, S. Zoughbi, and F. González, "Smart government: Opportunities and challenges in smart cities development," in Handbook of Research on Democratic Strategies and Citizen-Centered EGovernment Services: IGI Global, 2015, pp. 1-19.

[27] L. F. Luna-Reyes, J. Zhang, J. R. Gil-García, and A. M. Cresswell, "Information systems development as emergent socio-technical change: a practice approach," European Journal of Information Systems, vol. 14, no. 1, pp. 93-105, 2005.

[28] C. Juiz, C. Guerrero, and I. Lera, "Implementing good governance principles for the public sector in information technology governance frameworks," Open Journal of Accounting, vol. 3, no. 01, p. 9, 2014.

[29] G. S. Dawson, J. S. Denford, C. K. Williams, D. Preston, and K. C. Desouza, "An examination of effective IT governance in the public sector using the legal view of agency theory," Journal of Management Information Systems, vol. 33, no. 4, pp. 1180-1208, 2016.

[30] S. L. Caudle, W. L. Gorr, and K. E. Newcomer, "Key information systems management issues for the public sector," MIS quarterly, pp. 171-188, 1991.

[31] L. A. de Looff, "IS outsourcing by public sector organisations," in Advanced IT Tools: Springer, 1996, pp. 89-94.

[32] J. E. Fountain, Building the virtual state: Information technology and institutional change. Brookings Institution Press, 2001.

[33] V. Mayer-Schönberger and K. Cukier, "Big Data: A Revolution That Will Transform How We Live, Work, and Think," ed. Boston, Massachusetts: Houghton Mifflin Harcourt, 2014.

[34] J. Mullich, "Closing the big data gap in public sector," SURVEY REPORT-Real-Time Enterprise,(Sep. 2013), 2013.
[35] M. Milakovich, "Anticipatory government: Integrating big data for smaller government," Internet, Politics, Policy 2012: Big Data, Big Challenges, 2012.

[36] H. Margetts and D. Sutcliffe, "Addressing the policy challenges and opportunities of "Big data"," Policy \& Internet, vol. 5, no. 2, pp. 139-146, 2013.

[37] J. Manyika et al., Big data: The next frontier for innovation, competition, and productivity, McKinsey Global Institute, 2011.

[38] F. Malomo and V. Sena, "Data Intelligence for Local Government? Assessing the Benefits and Barriers to Use of Big Data in the Public Sector," Policy \& Internet, vol. 9, no. 1, pp. 7-27, 2017.

[39] A. Aggarwal, "A Hybrid Approach to Big Data Systems Development," Managing Big Data integration in the public sector, pp. 20-37, 2016.

[40] M. van Rijmenam, Think bigger: Developing a successful big data strategy for your business. Amacom, 2014.

[41] L. Chambers, V. Dimitrova, and R. Pollock, "Technology for transparent and accountable public finance," A Report by the Open Knowledge Foundation, 2012.

[42] P. V. Thakuriah, N. Y. Tilahun, and M. Zellner, "Big data and urban informatics: innovations and challenges to urban planning and knowledge discovery," in Seeing Cities Through Big Data: Springer, 2017, pp. 11-45.

[43] T. Pearson and R. Wegener, "Big data: the organizational challenge," Bain Co, 2013.

[44] G. Rowe and G. Wright, "The Delphi technique as a forecasting tool: issues and analysis," International Journal of Forecasting, vol. 15, no. 4, pp. 353-375, 1999.

[45] R. C. Schmidt, "Managing Delphi surveys using nonparametric statistical techniques," Decision Sciences, vol. 28, no. 3, pp. 763-774, 1997.

[46] R. El-Gazzar, E. Hustad, and D. H. Olsen, "Understanding cloud computing adoption issues: A Delphi study approach," Journal of Systems and Software, vol. 118, pp. 64-84, 2016. 
Appendix 1 - Main challenges faced by organizations regarding the evolution and the maintenance of its IT infrastructure Brainstorming phase

\begin{tabular}{|c|c|}
\hline \multicolumn{2}{|c|}{ Category \#1 - STRATEGIC CHALLENGES } \\
\hline$L A B E L S$ & DEFINITIONS \\
\hline $\begin{array}{l}\text { 1) Balancing the } \\
\text { IT portfolio }\end{array}$ & $\begin{array}{l}\text { To be able to adequately allocate budgets to } \\
\text { ensure a balance between the needs in terms } \\
\text { of maintenance operation and system } \\
\text { evolution (innovations, investment in } \\
\text { infrastructure). }\end{array}$ \\
\hline $\begin{array}{l}\text { 2) Competence to } \\
\text { manage clients' } \\
\text { needs and } \\
\text { deadlines while } \\
\text { respecting IT } \\
\text { standards }\end{array}$ & $\begin{array}{l}\text { Be able to find a balance between responding } \\
\text { quickly to customer needs and adhering to } \\
\text { rules and standards that ensure the integrity of } \\
\text { the technology infrastructure. }\end{array}$ \\
\hline $\begin{array}{l}\text { 3) Organization- } \\
\text { wide availability of } \\
\text { business } \\
\text { intelligence tools }\end{array}$ & $\begin{array}{l}\text { Make business intelligence tools available to } \\
\text { employees across all business units and not } \\
\text { just for the IT employees. }\end{array}$ \\
\hline 4) IT legal issues & $\begin{array}{l}\text { Legal issues (intellectual property, data } \\
\text { ownership, etc.) can hinder the adoption of } \\
\text { new technologies such as cloud computing, } \\
\text { blockchain. }\end{array}$ \\
\hline $\begin{array}{l}\text { 5) Flexibility of the } \\
\text { IT infrastructure }\end{array}$ & $\begin{array}{l}\text { To be able to build a flexible infrastructure } \\
\text { that can adapt to a rapidly changing } \\
\text { environment and support the organization to } \\
\text { identify and exploit new business } \\
\text { opportunities. }\end{array}$ \\
\hline $\begin{array}{l}\text { 6) Manage upper } \\
\text { management's } \\
\text { expectations and } \\
\text { clarify the } \\
\text { importance of } \\
\text { infrastructure } \\
\text { management }\end{array}$ & $\begin{array}{l}\text { Expectations in terms of reduced costs related } \\
\text { to infrastructure management are important } \\
\text { and IT managers need to be able to explain } \\
\text { the importance of maintaining and evolving } \\
\text { the IT infrastructure in order to get the } \\
\text { appropriate budgets and realistic deadlines. } \\
\text { This is made difficult because infrastructure } \\
\text { management projects do not always add value } \\
\text { to the business and that upper management } \\
\text { sometimes downplays the challenges } \\
\text { associated with the managing a complex and } \\
\text { rapid evolving infrastructure. }\end{array}$ \\
\hline 7) Inertia & $\begin{array}{l}\text { Be able to evolve existing processes and } \\
\text { procedures, so that the infrastructure can } \\
\text { develop; adopt new solutions and avoid } \\
\text { inertia and the status quo. }\end{array}$ \\
\hline $\begin{array}{l}\text { 8) Make } \\
\text { organizational } \\
\text { members aware of } \\
\text { the complexity of } \\
\text { infrastructure } \\
\text { management }\end{array}$ & $\begin{array}{l}\text { In a context where IT and related knowledge } \\
\text { permeate the organizational structure, it is } \\
\text { important to be able to explain complex } \\
\text { infrastructure management issues across an } \\
\text { organization so that expectations are realistic. }\end{array}$ \\
\hline $\begin{array}{l}\text { 9) Make informed } \\
\text { business decisions }\end{array}$ & $\begin{array}{l}\text { Be able to clearly identify business needs and } \\
\text { make informed decisions to evolve the } \\
\text { infrastructure so that it can support an } \\
\text { organization in pursuit of new business } \\
\text { opportunities. }\end{array}$ \\
\hline $\begin{array}{l}\text { 10) Complex } \\
\text { acquisition process } \\
\text { (public } \\
\text { organization) }\end{array}$ & $\begin{array}{l}\text { To be able to adapt to the complex standards } \\
\text { and regulations that govern the acquisition of } \\
\text { IT solutions in the public domain. }\end{array}$ \\
\hline
\end{tabular}

11) Regulations and control of employee-owned

IT

\section{2) Relationship with suppliers}

\section{3) Compliance}

with laws, standards and regulations

14) Structure and governance of the IT department

IT department

15) Organizational
Transformation

\section{Transformation}

16) Valuation of Assets

\section{Category \#2 - TECHNOLOGICAL CHALLENGES}

To be able to maintain coherence in the infrastructure by avoiding fragmentation and

17) Coherent infrastructure redundancy of systems. For new projects, it is important to be able to reuse existing infrastructure components rather than add new ones at the risk of adding redundancy in the infrastructure.

To be able to have the most accurate and complete understanding of an often very complex infrastructure and to be able to document it. This requires understanding not only the composition of the infrastructure (the various elements such as servers, routers, software), the integration of these different components and the link with the business

18) Understanding and documenting current infrastructure and architecture services rendered. This aspect is important to ensure the coherence of the infrastructure and to avoid redundancy in the services offered. In addition, different factors may complicate this task over time, such as the loss of knowledge related to the departure of employees (i.e., retired or to competition) and the sometimeslimited documentation on certain components of the infrastructure. 


\begin{tabular}{|c|c|}
\hline $\begin{array}{l}\text { 19) Rapid } \\
\text { evolution of IT } \\
\text { infrastructure } \\
\text { components }\end{array}$ & $\begin{array}{l}\text { To be able to understand and anticipate the } \\
\text { evolution of the market (technology watch), } \\
\text { to make informed choices in relation to new } \\
\text { technologies that appear constantly and / or to } \\
\text { face the pressure of suppliers in terms of } \\
\text { technological evolution. }\end{array}$ \\
\hline $\begin{array}{l}\text { 20) Business } \\
\text { Fusion and } \\
\text { Infrastructure } \\
\text { Integration } \\
\end{array}$ & $\begin{array}{l}\text { To be able to integrate infrastructures in a } \\
\text { consistent way when acquiring organizations. }\end{array}$ \\
\hline $\begin{array}{l}\text { 21) Capacity } \\
\text { Management }\end{array}$ & $\begin{array}{l}\text { To be able to assess the needs of the } \\
\text { organization in terms of system capacity in } \\
\text { order to be able to evolve the infrastructure } \\
\text { accordingly. }\end{array}$ \\
\hline $\begin{array}{l}\text { 22) Cloud } \\
\text { application } \\
\text { management }\end{array}$ & $\begin{array}{l}\text { The management of cloud applications is } \\
\text { complex knowing that the updates and } \\
\text { evolutions of the applications are not under } \\
\text { the control of the IT department and that these } \\
\text { evolutions can occur at a fast pace. }\end{array}$ \\
\hline \begin{tabular}{|l|} 
Im) \\
Implementation \\
of automation tools \\
and artificial \\
intelligence \\
\end{tabular} & $\begin{array}{l}\text { Be able to identify, develop, implement and } \\
\text { maintain job automation and artificial } \\
\text { intelligence tools to support the management } \\
\text { of the IT infrastructure. }\end{array}$ \\
\hline $\begin{array}{l}\text { 24) Complex } \\
\text { integration of } \\
\text { infrastructure }\end{array}$ & $\begin{array}{l}\text { To be able to take into consideration the } \\
\text { integration of the different components of the } \\
\text { infrastructure during the evolution of a part of } \\
\text { this infrastructure. At the technical level, this } \\
\text { integration poses challenges in terms of } \\
\text { evolution projects complexity (i.e., problems } \\
\text { related to compatibility, standards, evolving } \\
\text { security standards) and entails additional } \\
\text { costs. At the organizational level, the fact that } \\
\text { different parts of the infrastructure are } \\
\text { distributed and under the responsibility of } \\
\text { different stakeholders (e.g., IT department, } \\
\text { external contractor) further complicates the } \\
\text { evolution of this infrastructure. }\end{array}$ \\
\hline $\begin{array}{l}\text { 25) Cloud } \\
\text { integration }\end{array}$ & $\begin{array}{l}\text { To be able to manage the integration between } \\
\text { different cloud services, as well as between } \\
\text { them and the existing infrastructure. This } \\
\text { integration can be complicated by the lack of } \\
\text { interoperability between different services. }\end{array}$ \\
\hline \begin{tabular}{|l|} 
26) Systems' \\
interoperability
\end{tabular} & $\begin{array}{l}\text { Consider the lack of interoperability between } \\
\text { the systems offered by the different providers. }\end{array}$ \\
\hline $\begin{array}{l}\text { 27) Maintaining an } \\
\text { aging } \\
\text { infrastructure }\end{array}$ & $\begin{array}{l}\text { Maintaining aging infrastructure is complex } \\
\text { and the difficulty of obtaining the necessary } \\
\text { replacement components for maintenance } \\
\text { makes this task even more difficult. }\end{array}$ \\
\hline \multicolumn{2}{|c|}{ Category \#3 - SECURITY CHALLENGES } \\
\hline $\begin{array}{l}\text { 28) Data } \\
\text { Management in } \\
\text { Public and Hybrid } \\
\text { Clouds }\end{array}$ & $\begin{array}{l}\text { The tendency of users to use external services } \\
\text { (BYOD, third-party applications, etc.) poses } \\
\text { significant challenges in terms of enterprise } \\
\text { data management. When the organization's } \\
\text { data is stored in different places, it becomes } \\
\text { difficult to guarantee data integrity (are the } \\
\text { data saved?), their security (does the platform } \\
\text { protect adequately data access?) and this also } \\
\text { poses challenges in terms of data ownership. }\end{array}$ \\
\hline $\begin{array}{l}\text { 29) Piracy and } \\
\text { data security }\end{array}$ & $\begin{array}{l}\text { To be able to cope with the risks of data } \\
\text { piracy by implementing the necessary } \\
\text { protection mechanisms. }\end{array}$ \\
\hline
\end{tabular}

\begin{tabular}{|c|c|}
\hline $\begin{array}{l}\text { 30) Standards and } \\
\text { best practices in } \\
\text { data security }\end{array}$ & $\begin{array}{l}\text { To be able to adapt to the many security } \\
\text { standards and practices that are constantly } \\
\text { evolving and evolving to ensure data security. }\end{array}$ \\
\hline \multicolumn{2}{|c|}{ Category \#4 - HUMAN RESOURCES CHALLENGES } \\
\hline $\begin{array}{l}\text { 31) Skill } \\
\text { development }\end{array}$ & $\begin{array}{l}\text { To be able to identify, develop and update the } \\
\text { skills and expertise of employees in relation } \\
\text { to constantly evolving technologies. For this, } \\
\text { it is important to know the existing training } \\
\text { and be able to find the right training for the } \\
\text { right person. }\end{array}$ \\
\hline $\begin{array}{l}\text { 32) Knowledge } \\
\text { Management }\end{array}$ & $\begin{array}{l}\text { To be able to maintain and avoid losing } \\
\text { knowledge in the organization, when } \\
\text { employees leave for other departments or } \\
\text { companies, or when they retire }\end{array}$ \\
\hline $\begin{array}{l}\text { 33) Recruitment of } \\
\text { employees }\end{array}$ & $\begin{array}{l}\text { To be able to recruit competent and qualified } \\
\text { employees in the IT field. The rapid evolution } \\
\text { and the diversity of technologies involves } \\
\text { recruiting people with multiple skills } \\
\text { (versatility) and who are able to continue } \\
\text { learning. In addition, the current market is } \\
\text { facing a labor shortage which complicates the } \\
\text { management of the IT infrastructure. This } \\
\text { shortage is accentuated for skills in some } \\
\text { emerging fields (e.g., big data analysis) or } \\
\text { conversely related to older technologies that } \\
\text { are no longer taught (some code, database } \\
\text { languages, etc.). }\end{array}$ \\
\hline $\begin{array}{l}\text { 34) Employee } \\
\text { retention }\end{array}$ & $\begin{array}{l}\text { To be able to retain employees in order to } \\
\text { maintain the necessary skills to manage the } \\
\text { infrastructure. Due to the labor shortage in the } \\
\text { field, skilled employees are in high demand } \\
\text { and job rotation is important. }\end{array}$ \\
\hline \multicolumn{2}{|c|}{$\begin{array}{c}\text { Category \#5 - FINANCIAL RESOURCES AND COST } \\
\text { CONTROL CHALLENGES }\end{array}$} \\
\hline $\begin{array}{l}\text { 35) Limited } \\
\text { resources for } \\
\text { infrastructure } \\
\text { management }\end{array}$ & $\begin{array}{l}\text { The complexity of managing infrastructure } \\
\text { entails significant costs in new projects } \\
\text { (planning, development, testing, production) } \\
\text { and the lack of allocated resources hinders } \\
\text { infrastructure development projects. }\end{array}$ \\
\hline $\begin{array}{l}\text { 36) License } \\
\text { Tracking }\end{array}$ & $\begin{array}{l}\text { Being able to track licenses is a complex } \\
\text { process. Indeed, it is necessary to be in good } \\
\text { standing and compliant during audits of } \\
\text { software publishers. }\end{array}$ \\
\hline \multicolumn{2}{|c|}{ Category \#6 - USERS RELATED CHALLENGES } \\
\hline $\begin{array}{l}\text { 37) Access to high- } \\
\text { performance } \\
\text { telecommunication } \\
\text { infrastructures }\end{array}$ & $\begin{array}{l}\text { Consider differences in telecommunication } \\
\text { infrastructures performance, given that some } \\
\text { regions are still underserved in terms of } \\
\text { access to high-speed internet. }\end{array}$ \\
\hline 38) User needs & $\begin{array}{l}\text { To be able to understand and adapt to the } \\
\text { needs of users who are constantly evolving. In } \\
\text { fact, the use of IT is democratizing and the } \\
\text { needs of users are changing according to the } \\
\text { experiences they acquire in the organizational } \\
\text { context or outside (i.e., with smart phones, } \\
\text { social networks, etc.). These new needs are, } \\
\text { for example, the accessibility of data anytime } \\
\text { and anywhere, the support of different media } \\
\text { (computers, smartphones, tablets, etc.) and the } \\
\text { user experience (more intuitive applications, } \\
\text { easy to use). }\end{array}$ \\
\hline
\end{tabular}




\section{Appendix 2 - Results of the Narrowing and the Ranking phases}

Note: Nar. = Narrowing phase Ran. $=$ Ranking phase; $\mathbf{X}=$ Challenges identified as important; \#1 to $\mathbf{1 4}=$ Order or importance

\begin{tabular}{|c|c|c|c|c|c|c|}
\hline \multirow{3}{*}{$\begin{array}{l}\text { Main challenges faced by organizations regarding the } \\
\text { evolution and the maintenance of its IT infrastructure } \\
\text { (not classified in particular order) }\end{array}$} & \multicolumn{6}{|c|}{ Participants' Sectors } \\
\hline & \multicolumn{2}{|c|}{ Private sector } & \multicolumn{2}{|c|}{ Public sector } & \multicolumn{2}{|c|}{ Academic } \\
\hline & Nar. & Ran. & Nar. & Ran. & Nar. & Ran. \\
\hline 1) Balancing the IT portfolio & $\mathbf{X}$ & 7 & & & & \\
\hline $\begin{array}{l}\text { 2) Competence to manage clients' needs and deadlines while } \\
\text { respecting IT standards }\end{array}$ & & & $\bar{X}$ & 10 & & \\
\hline \multicolumn{7}{|l|}{$\begin{array}{l}\text { 3) Organization-wide availability of business intelligence } \\
\text { tools }\end{array}$} \\
\hline \multicolumn{7}{|l|}{ 4) IT legal issues } \\
\hline 5) Flexibility of the IT infrastructure & $\mathbf{X}$ & 9 & $\boldsymbol{X}$ & 12 & $\mathbf{X}$ & 6 \\
\hline $\begin{array}{l}\text { 6) Manage upper management's expectations and clarify } \\
\text { importance of infrastructure management }\end{array}$ & $\mathbf{X}$ & 10 & $\bar{X}$ & 11 & & \\
\hline \multicolumn{7}{|l|}{ 7) Inertia } \\
\hline \multicolumn{7}{|l|}{$\begin{array}{l}\text { 8) Make organizational members aware of the complexity of } \\
\text { infrastructure management }\end{array}$} \\
\hline 9) Make informed business decisions & & & $X$ & 7 & & \\
\hline \multicolumn{7}{|l|}{ 10) Complex acquisition process (public organization) } \\
\hline \multicolumn{7}{|l|}{ 11) Regulations and control of employee-owned IT } \\
\hline \multicolumn{7}{|l|}{ 12) Relationship with suppliers } \\
\hline 13) Compliance with laws, standards and regulations & & & $X$ & 5 & $\mathbf{X}$ & 10 \\
\hline 14) Structure and governance of the IT department & $\mathbf{X}$ & 3 & $X$ & 2 & $\mathbf{X}$ & 5 \\
\hline 15) Organizational Transformation & $\mathbf{X}$ & 1 & $\boldsymbol{X}$ & 1 & $\mathbf{X}$ & 1 \\
\hline \multicolumn{7}{|l|}{ 16) Valuation of Assets } \\
\hline \multicolumn{7}{|l|}{ 17) Coherent infrastructure } \\
\hline $\begin{array}{l}\text { 18) Understanding and documenting current infrastructure } \\
\text { and architecture }\end{array}$ & & & $\boldsymbol{X}$ & 15 & & \\
\hline 19) Rapid evolution of IT infrastructure components & $\mathbf{X}$ & 4 & & & & \\
\hline \multicolumn{7}{|l|}{ 20) Business Fusion and Infrastructure Integration } \\
\hline \multicolumn{7}{|l|}{ 21) Capacity Management } \\
\hline \multicolumn{7}{|l|}{ 22) Cloud application management } \\
\hline $\begin{array}{l}\text { 23) Implementation of automation tools and artificial } \\
\text { intelligence }\end{array}$ & & & $\bar{X}$ & 9 & $\mathbf{X}$ & 12 \\
\hline 24) Complex integration of infrastructure & & & $X$ & 8 & $\mathbf{X}$ & 4 \\
\hline 25) Cloud integration & $\mathbf{X}$ & 14 & & & $\mathbf{X}$ & 7 \\
\hline \multicolumn{7}{|l|}{ 26) Systems' interoperability } \\
\hline 27) Maintaining an aging infrastructure & $\mathbf{X}$ & 6 & $X$ & 13 & & \\
\hline \multicolumn{7}{|l|}{ 28) Data Management in Public and Hybrid Clouds } \\
\hline 29) Piracy and data security & $\mathbf{X}$ & 8 & & & $\mathbf{X}$ & 3 \\
\hline 30) Standards and best practices in data security & & & & & $\mathbf{X}$ & 11 \\
\hline 31) Skill development & $\mathbf{X}$ & 13 & $X$ & 14 & $\mathbf{X}$ & 8 \\
\hline 32) Knowledge Management & $\mathbf{X}$ & 5 & $X$ & 4 & $\mathbf{X}$ & 2 \\
\hline 33) Recruitment of employees & $\mathbf{X}$ & 12 & $X$ & 6 & & \\
\hline 34) Employee retention & $\mathbf{X}$ & 2 & $X$ & 3 & $\mathbf{X}$ & 9 \\
\hline \multicolumn{7}{|l|}{ 35) Limited resources for infrastructure management } \\
\hline \multicolumn{7}{|l|}{ 36) License Tracking } \\
\hline \multicolumn{7}{|l|}{$\begin{array}{l}\text { 37) Access to high-performance telecommunication } \\
\text { infrastructures }\end{array}$} \\
\hline 38) User needs & $\mathbf{X}$ & 11 & & & & \\
\hline
\end{tabular}

